\title{
A Literature Synthesis of Experimental Studies on Management Earnings Guidance
}

\author{
Jun Han \\ Associate Professor \\ School of Business \\ The University of Hong Kong \\ Pokfulam Road, Hong Kong \\ Tel: (852) 39175846 \\ Fax: (852) 28585614 \\ Email: junhan@business.hku.hk
}

May 2013

Journal of Accounting Literature, forthcoming

I highly appreciate comments from Stephen Asare (the editor), an anonymous reviewer, Wei Chen, Terrence Bu Peow Ng, Chul Park, Hun-Tong Tan, and Seet Koh Tan. All errors are my own. I highly appreciate excellent research assistance work offered by Yifei Xia. This paper was supported by a grant from the Research Grants Council of the Hong Kong Special Administrative Region, China (project no. HKU 744009H). 


\section{A Literature Synthesis of Experimental Studies on Management Earnings Guidance}

Researchers have long been interested in understanding why and how corporate managers issue earnings guidance and the effect of such guidance on stakeholders' (investors' and managers') behavior. Several recent studies have employed the experimental approach to address these issues. The purpose of this paper is to analyze and synthesize the literature on experimental studies of management earnings guidance. Consistent with the literature, I organize the synthesis to reflect (a) whether, why and how management issues guidance; (b) investors' reactions to guidance; (c) the effect of guidance on management behavior. In addition, I provide institutional information (e.g., nature and timing of guidance) about guidance as well as provide several directions for future research. The synthesis reveals that the experimental studies have made a unique contribution to this literature by (i) providing evidence on process variables that underlie some empirical associations, (ii) directly measuring managers' personal attributes and, (iii) closing the causality gap in the guidance literature.

Keywords: Experiment; financial accounting; management earnings guidance; management forecast 


\section{INTRODUCTION}

Management earnings guidance, or management forecast, refers to "a company publicly disclosing its own projections of its financial results for the upcoming quarter or fiscal year" [Diamond and Yevmenenko, 2011, p. 44]. ${ }^{1}$ Researchers have had a long and continuing interest in examining the antecedents, characteristics, and consequences of management earnings guidance [for a review, see Hirst et al., 2008]. The earliest research focused primarily on using archival methods to test economic theories of earnings guidance (see Cameron [1986] and King et al. [1990] for reviews). Several recent studies have employed the experimental approach to test psychology theories of earnings guidance (see Hirst et al. [2008] for a review across all methodologies).

Experimental studies in this area are important since they provide unique advantages that are unavailable to other paradigms. First, experimenters are able to hold information constant across treatment conditions, and are better able to establish stronger causal relation between the independent and dependent variables [Libby et al., 2002]. Second, experimenters can measure process variables and provide answers to questions such as why certain phenomena occur [Libby et al., 2002]. Finally, experimental research is able to provide ex ante evidence on guidance issues for which little or no archival data are available [e.g.,Nelson and Rupar, 2011]. It thus may contribute to accounting policy research [Maines, 1994]. Hence, the experimental approach has the potential to shed important insights on why and how corporate managers issue earnings guidance and the effect of such guidance on stakeholders' (investors' and managers') behavior.

The purpose of this paper is to provide a comprehensive analysis and synthesis of experimental research on management earnings guidance. This literature synthesis is important

\footnotetext{
${ }^{1}$ Several other terms have been used in the literature to refer to particular types of management earnings guidance. For example, earnings guidance for negative earnings prospects may be referred to as "earnings warnings" [e.g., Libby and Tan, 1999].
} 
in assessing the unique insights that experimental research has offered in understanding the guidance literature, identifying gaps in the literature, evaluating the extent to which the experimental research corroborates or contradicts archival findings and identifying unresolved and important issues for further research. A synthesis is also important to managers, who seek to make better disclosure decisions by shedding light on how investors react to disclosures, and to regulators, who seek evidence of how investors are impacted by voluntary disclosures, such as earnings guidance [Elliott et al., 2007].

The experimental literature has concerned itself with whether or not management will issue guidance and, if they do, why and how the guidance is issued [e.g., Libby and Rennekamp, 2012]. Researchers have also been interested in the effect of the presence, nature and form of guidance on investors [e.g., Libby and Tan, 1999]; and finally, how does the commitment to guide affect management's contemporaneous and subsequent operating and disclosure behaviors [Wang and Tan, 2013]. Corresponding to this research focus, the remainder of this paper is structured as follows. I provide background information about the guidance environment by introducing and defining key terms and concepts in the next section. The organizing framework for synthesizing the extant research follows this (Section 3). In Section 4, I provide a synthesis of the literature on whether, why and how corporate managers issue earnings guidance. In Section 5, I synthesize the literature on whether, how and why investors react to management guidance. Section 6 focuses on whether and how the decision to guide affects the guider's behavior. The last section explores directions for future research and offers concluding remarks.

\section{BACKGROUND AND CONCEPTS}

Some public companies have a long history of voluntarily disclosing projections of their financial results for the upcoming quarter or fiscal year. This practice, referred to as providing 
earnings guidance, became more common during the latter half of the 1990s, after the US congress enacted the Private Securities Litigation Reform Act of 1995, which included safe harbor provisions for such projections [Hsieh et al., 2006]. The impetus for providing guidance is a subject of continuing debate with lower share price volatility, higher valuations, stock liquidity and maintaining good communication with market participants cited as some of the potential benefits [Hsieh et al., 2006]. In recent years, there has been a slow down in the rate of growth in the number of companies issuing guidance and some companies, like general Electric and McDonald's corporation, have stopped issuing guidance [also called "going dark"; Fuller and Jensen, 2010].

It is this institutional richness that has attracted research into the earnings guidance process. In the remainder of this section, I introduce and define several key terms and concepts that researchers employ in this literature to facilitate the subsequent analysis and synthesis.

\subsection{Guidance Timeline}

Guidance timeline issues arise because of management's ability to control the timing of earnings guidance. Management may provide earnings guidance at any time before the actual earnings announcement date [i.e., the release of actual earnings; Hirst et al., 2008)]. ${ }^{2}$ Usually the earnings guidance for the upcoming quarter or fiscal year is short-term guidance while guidance for more distant fiscal period is long-term guidance [Cheng et al., 2005]. There is interdependence between management earnings guidance and analysts’ earnings forecasts. One motive for managers to provide earnings guidance is to align market expectation (primarily the analysts' forecasts) with their own earnings expectations [Ajinkya and Gift, 1994].

\footnotetext{
${ }^{2}$ US federal securities law require companies to only file an annual report on the Form $10 \mathrm{~K}$ or a quarterly report on the Form 10Q. In practice, most companies voluntarily release their earnings before filing their annual or quarterly reports [Hsieh et al., 2006].
} 
Correspondingly, researchers generally find that analysts often revise their earnings forecasts subsequent to management earnings guidance [e.g., Baginski and Hassell, 1990].

Management often provides earnings guidance contemporaneous, in time and venue (e.g., at the earnings conference call), with the announcement of the current actual earnings results. This phenomenon is commonly referred to as "bundled guidance" [Rogers and Buskirk, 2013; for additional institutional information on the intersection of earnings guidance and earnings release, see Diamond and Yevmenenko, 2011].

\subsection{Guidance News Valence}

The guided EPS (Earnings per Share) is usually compared with an earnings benchmark to define its news valence; i.e., whether the guidance news is positive (when the guided EPS is more positive than the benchmark) or negative (when the guided EPS is more negative than the benchmark). If there are analysts following the guiding company, usually the analysts' consensus forecast (mean forecast of all analysts following the guiding company) is used as a proxy for the market expectation at that time and therefore the comparison benchmark [e.g., Tan et al., 2002]. An alternative earnings benchmark, if there is no analysts' consensus forecast available, can be prior EPS [Degeorge et al., 1999].

\subsection{Guidance News Division}

At the time that actual earnings become available, comparisons can be made among the actual earnings, the prior guided earnings and the relevant benchmark (as discussed above). In this vein, "total earnings news" is defined as the difference between actual EPS and the most recent relevant benchmark. Total earnings news can be decomposed into "guidance news" and "actual earnings news." Guidance news refers to the difference between guided EPS and the relevant benchmark just prior to the guided EPS. Actual earnings news refers to the difference 
between guided and actual EPS [Tan et al., 2002]. A guiding firm has non-zero guidance news, and total earnings news is split into guidance news and actual earnings news. In particular, a guiding firm has no actual earnings news and guidance news equals to total earnings news if the guided EPS equals to actual EPS. A non-guiding firm, obviously, has no guidance news and total earnings news equals to actual earnings news.

\subsection{Guidance Forms}

Managers may choose different forms of guidance that reflect different degrees of precision [Hughes and Pae, 2004]. In particular, earnings guidance can take the form of point guidance, range guidance, one-sided (minimum or maximum) guidance, and qualitative guidance, in descending order of precision [e.g., Han and Tan, 2007]. ${ }^{3}$ Archival studies generally show that managers use different guidance forms to express their uncertainty regarding future earnings [Hirst et al., 2008]. The higher the environmental uncertainty, the less precise the earnings guidance becomes [Hughes and Pae, 2004].

\subsection{Guidance Accuracy and Bias}

Guidance accuracy is defined by comparing the guided EPS with the actual EPS; i.e., the smaller the magnitude for the actual earnings news, the more accurate the earnings guidance is. There is an upward (downward) bias when guided EPS is higher (or lower) than the actual EPS. If guided EPS is always biased in a given direction with the same magnitude, the bias is a consistent bias. In contrast, if EPS guidance is always biased in a given direction but with varying magnitudes, it is referred to as an inconsistent bias [Tan et al., 2010].

\footnotetext{
${ }^{3}$ There is a single number provided in the typical point guidance (e.g., "EPS for this quarter is expected to be \$1"). There are both maximum and minimum limits provided in the typical range guidance (e.g., "EPS for this quarter is expected to be between $\$ 0.9$ and $\$ 1.1$ ”). If there is only a maximum (minimum) limit available in earnings guidance, it is a one-sided guidance (e.g., "EPS for this quarter is expected be to more than (less than) \$1"). Finally, in a qualitative guidance, there is no number but only a narrative description (e.g., "I am optimistic about EPS for this quarter").
} 


\subsection{Guidance Frequency and Guidance Commitment}

Guidance frequency refers to how often a company provides earnings guidance. In the sample of Bhojroj et al. [2012], 10.75\% companies provide earnings guidance only once in a year; while around 34.45\% companies provide earnings guidance 10 times or more annually. Guidance predictability is defined by how easily outsiders (such as the analysts) are able to predict whether, how, and when managers may provide earnings guidance in the future based on their historical earnings guidance pattern [Venkataraman, 2008]. "For example, a firm that issues three forecasts over a three-year period and does so every year in December is a more committed discloser relative to a firm that issues three forecasts in a random fashion over that same time period” [Venkataraman, 2008, p. 6]. Guidance commitment is defined on both guidance frequency and guidance predictability so that a more frequent and/or more predictable guider is more committed than a less frequent and/or less predictable guider [Venkataraman, 2008].

\subsection{Guidance Disaggregation}

Managers often provide their earnings guidance with other quantitative or qualitative information [e.g., Hirst et al., 2007]. When management earnings guidance is accompanied with guidance on other income statement line items (e.g., revenue, cost of goods sold, etc.,) it is called “disaggregated earnings guidance.” In contrast, it is known as “aggregated earnings guidance” if guidance is provided only for the bottom-line earnings numbers [net income, EPS, etc.; Hirst et al., 2007].

To sum up, a guiding company has discretion not just over the guidance decision but also over the timing, form, frequency, level of aggregation, and consistency of the guidance. Further, guiding companies may decide to stop providing guidance. Once guidance is provided, market participants can assess the information content, accuracy, bias and valance of the guidance using 
various benchmarks. In turn, these issues raise a plethora of researchable questions, several of which have been studied using experimental techniques. I next present an organizing framework that I used to discuss these experimental studies.

\section{Organizing Framework}

Figure 1 presents the organizing framework for the synthesis, which captures experimental researchers' current focus on understanding management's decision to guide and how that decision affects investors and management. In the framework, management decides to guide (or not to guide) and the nature, form, and frequency of this guidance. I refer to these as the guidance characteristics. Research has examined guider and environmental attributes that affect the decision to guide and the guidance characteristics. Guider attributes are attributes of the guiding firm or management, such as the firm's earnings record and the manager's personal attributes. Environmental factors are factors outside of the firm and/or management's control that may play a role in the management earnings guidance process. This includes the operating and regulatory environment, peer company's earnings guidance behavior, etc. The second strand of research has focused on the effect of the guidance characteristics (sometimes interacting with the guider attributes and/or the environmental attributes) on investors and management.

Accordingly, I first analyze and synthesize the literature on guider attributes and/or environmental attributes that determine whether and how management issue earnings guidance (Section 4). Next, I synthesize the literature on investors' reactions to guidance (Section 5). Finally, I discuss how guidance can affect the guider (Section 6).

Hirst et al. [2008] employ a framework of forecast antecedents - forecast characteristics forecast consequences to review the area of management earnings guidance (including both experimental and archival studies). My synthesis extends their important work in three respects. 
First, I separately compare guiding firms versus non-guiding firms (in Section 5.2.1), which is not discussed by Hirst et al. [2008]. Second, in Hirst et al. [2008], both environmental factors and forecaster characteristics (comparable to guider attributes in my framework) are forecast antecedents that determine whether management issue earnings guidance. In contrast, in my review, guider attributes and environmental factors appear as both guidance determinants and moderators of the effect of guidance characteristics, according to whether such guider attributes and/or environmental factors affect management earnings guidance decision or investors' reactions to management earnings guidance. Third, I further divide guidance characteristics into guidance record characteristics and specific guidance characteristics, which is absent in Hirst et al. [2008].

Insert Figure 1 Here

\section{Whether, Why and How Management Issues Guidance}

As indicated in Figure 1, research has examined guider and environmental attributes that affect the decision to guide and the guidance characteristics. With respect to guider attributes, prior research has examined the effect of guiders' confidence and incentives on whether and how to provide guidance. With respect to environmental attributes, prior research has examined the effect of environmental uncertainty on the form of guidance.

\subsection{Guider Attributes (Overconfidence Effect)}

There is a paucity of research on the extent to which managers' personal attributes affect their decision to guide. The only experimental study in this area is Libby and Rennekamp [2012], which shows that overconfident managers are more likely to perceive that the benefits associated 
with earnings guidance exceed its costs; hence, overconfident managers are more likely to issue earnings guidance. This finding holds regardless of whether the overconfidence is induced by self-serving attribution (attributing better task performance to skill or ability rather than to luck or the task being less difficult) or is an inherent personal trait [Libby and Rennekamp, 2012] . This experimental finding corroborates the archival study that shows that managers' overconfidence does affect their tendencies to issue earnings guidance at a market level [Hribar and Yang, 2011]. Compared with archival research, experimental studies have the advantage of providing a clean and direct measure of managers' personal attributes and hence more experimental studies are needed that examines the effects other personal attributes.

\subsection{Guider Attributes (Incentive-or-Pressure-to-Manipulate Effect)}

Managers who provide disaggregated guidance have the discretion over the choice of line items (e.g., revenue, research and development expenses, etc.) to add to the earnings guidance [Hirst et al., 2007]. Holderness and Hunton [2011] show that managers who are under pressure to manipulate earnings are more likely to disaggregate earnings guidance for line items that are not manipulated, but not to provide guidance on items where manipulations are involved. However, managers who do not face pressure to manipulate earnings are not likely to issue disaggregated guidance in such a strategic manner.

\subsection{Environmental Attributes (Environmental Uncertainty)}

Archival studies show that guidance form is often used to express management's estimation uncertainty [e.g., Hughes and Pae, 2004]. Specifically, the higher the earnings uncertainty, the less precise guidance form management tends to use [Hughes and Pae, 2004]. An experimental study by Du et al. [2011] corroborates this finding. Du et al. [2011] ask the participants in their experiment to provide their own earnings estimates, without restricting the 
form of the estimates. Du et al. [2011] find that participants are more likely to provide point estimates in a highly informed (therefore less uncertain) scenario, but they are more likely to provide range estimates in a poorly informed (therefore highly uncertain) scenario.

\section{HOW AND WHY INVESTORS REACT TO MANAGEMENT GUIDANCE}

In this section, I review studies on 1) how earnings guidance characteristics affect investors' reactions to the earnings guidance. Guidance characteristics are divided into: a) guidance record characteristics, i.e., how does management earnings guidance behave over time (Section 5.1); and b) specific (or one-time) guidance characteristics (Section 5.2). Next, I review how guider attributes and/or environmental attributes interact with guidance characteristics to affect investors' reactions (Section 5.3).

\subsection{Guidance Record Characteristics}

\subsubsection{Prior Guidance Accuracy (or Bias)}

Investors' reactions to current guidance forms depend on the firm's prior guidance record [Hirst et al., 1999]. One line of research focuses on prior guidance accuracy, that is, magnitude of the difference (be it positive or negative) between actual EPS and the guided EPS. This line of research shows that investors are more confident in their own earnings estimates when more precise point guidance is provided than less precise range guidance; but this effect only exists when the company has an accurate prior earnings guidance record. When the company has an inaccurate prior guidance record, investors do not react to guidance forms [Hirst et al., 1999].

In Hirst et al. [1999], prior management guidance is manipulated to be without obvious bias. Some studies investigate biased EPS guidance. For instance, Tan et al. [2010] show that compared to a consistent bias record, an inconsistent bias record gives analysts stronger excuse not to adjust for bias in earnings guidance. That is, analysts are more likely to follow earnings guidance (i.e., to copy management guided EPS in their own forecasts) if prior guidance is 
inconsistently biased (than consistently biased), even though the analysts are aware of the bias contained in management guidance.

\subsubsection{Guidance Frequency (or Guidance Commitment)}

Investors' views about a manager's commitment to disclosure also depend on the manager's prior guidance accuracy. More committed guiders are regarded as more credible than less committed guiders when prior guidance is accurate. When prior guidance is inaccurate, investors' views on more versus less committed guiders reverses; i.e., less committed guiders are more credible than more committed guiders [Venkataraman, 2008].

\subsubsection{Guidance Retractions and Corrections}

Managers sometimes retract or correct previous earnings guidance. "Retraction” refers to the cancellation or withdrawal of previous guidance, and "correction" refers to replacing the original erroneous disclosure with a new disclosure correcting any erroneous information contained in the previous disclosure. Tan and Koonce [2011] find that when there is a retraction of a piece of earnings-relevant news (but no new information is provided), the effect of previous erroneous information linger (i.e., investors cannot fully eliminate the impact of erroneous news even though they are explicitly informed of its invalidity). In contrast, when there is a correction (with new information provided), investors tend to overreact; i.e., they react more strongly to the correct news with the contrast of erroneous news, than to the correct news alone [Tan and Koonce, 2011].

\subsection{Specific Guidance Characteristics}

\subsubsection{Earnings News Division}

In this section, I review research on 1) how and why investors react differently to firms that guide versus firms that do not guide; and 2) how investors react differently for firms with 
different earnings news division strategies. While analysts claim that they welcome warnings of future earnings disappointments, archival researchers document that market reactions are more negative for firms that warn than for firms that do not warn [e.g., Kasznik and Lev, 1995]. Libby and Tan [1999] argue that the disparity between what analysts say (i.e., analysts welcome warnings of upcoming negative news) and what analysts do (i.e., analysts punish warnings firms) is a result of two processes: (1) analysts sequentially evaluate company earnings guidance and actual earnings when they make earnings and investment-related judgments, (2) analysts simultaneously review guidance and actual earnings news when they make comments about the desirability of earnings warnings. Libby and Tan [1999] provide evidence consistent with different information processing (sequential versus simultaneous) as an explanation for the seemingly paradoxical findings.

Libby and Tan [1999] examine investors' short-term reactions to guiding firms. Mercer [2005], in contrast, suggests that managers should not place too much emphasis on whether to provide earnings guidance. Mercer [2005] finds that, although in the short-term, management credibility is assessed to be higher for guiding firms than for non-guiding firms, in the long run management credibility is determined largely by whether total earnings news is positive or negative.

Assuming that managers are able to precisely predict total earnings news and they decide to issue earnings guidance, they need to decide how to split total earnings news into guidance news and actual earnings news. Broadly speaking, a manager can overstate, accurately state, or understate the total earnings news in his/her guidance. ${ }^{4}$ Tan et al. [2002] suggests that different

\footnotetext{
${ }^{4}$ For example, EPS for the coming quarter is 10 cents higher than the analysts' consensus forecast. In guidance, the firm manager may state in guidance that EPS will be 15 cents higher than the consensus analysts forecast (overstate), while the actual EPS is 5 cents lower than the guided EPS. The firm manager may state in guidance that EPS for the coming quarter will be 10 cents higher than the analysts' consensus forecast (accurately state), and the
} 
guidance strategy may lead to different investors' reactions, depending on whether total earnings news is positive or negative. Mental accounting theory [Thaler, 1999] suggests that providing two pieces of news with the same sign may increase investors' reactions relative to a single piece of news; in contrast, providing two pieces of news with contradicting signs may alleviate investors' reactions relative to a single piece of news. Based on this argument, Tan et al. [2002] suggest that for a firm with positive total earnings news, the best strategy is to split the total earnings news into two pieces of smaller positive news (i.e., to understate the positive total earnings news in its earnings guidance), and the worst strategy is to overstate the positive news in guidance, while having negative actual earnings news. In contrast, for a firm with negative total earnings news, the best strategy is to overstate the negative news in guidance, while having positive actual earnings news; and the worst strategy is to split the total earnings news into two pieces of smaller negative news (i.e., to understate the negative total earnings news in its earnings guidance). The effect of an accurate guidance strategy lies in the middle for both positive and negative domains.

Tan et al.'s [2002] findings are consistent with several theories. One is cue consistency theory, which argues that two earnings signals of consistent signs result in stronger investors' reactions than two earnings signals of opposite signs [Slovic, 1966]. The second theory is recency effect, which predicts that investors' reactions are predominantly determined by the more recent actual earnings news than by the earlier guidance news [Hogarth and Einhorn, 1992]. Another theory is diminishing marginal reaction theory, which predicts that investors' marginal reactions to an earnings signal diminish as the magnitude of the earnings news increases [Thaler, 1999]. Miller [2006] attempts to discriminate among the three theories and employs a setting of

actual EPS turns out be the same as the guidance. Or, the firm manager may state that EPS for the coming quarter will be 5 cents higher than the analysts' consensus forecast (understate), and the actual EPS turns out to be 5 cents higher than the guided EPS. 
understated positive total earnings news (i.e., both guidance news and actual earnings news are positive). There are three scenarios in Miller [2006]. One is that total earnings news is divided equally into guidance news and actual earnings news; one is that total earnings news is divided into a piece of larger guidance news and a piece of smaller actual earnings news; and the other scenario is that total earnings news is divided into a piece of smaller guidance news and a piece of larger actual earnings news. Cue consistency theory would predict similar reactions across the three scenarios. Recency theory predicts that investors' reactions are highest when the total earnings news is divided into a piece of large actual earnings news and a piece of small guidance news, followed by when the total earnings news is divided equally between the guidance news and the actual earnings news, then lowest when the total earnings news is divided into a piece of large guidance news and a piece of small actual earnings news. Diminishing marginal reaction theory predicts that investors' reactions would be stronger when the total earnings news is divided equally into the guidance news and the actual earnings news, relative to being divided into one piece of large news and one piece of small news. Miller's [2006] result is consistent with diminishing marginal reaction theory, but inconsistent with other competing theories such as cue consistency effect or recency effect.

The above studies examine the division between the guidance news and the actual earnings news in a single-firm setting. That is, they do not consider whether investors' reactions to a given firm's earnings guidance are affected by the guidance strategy of similar firms in the same industry. Maletta and Zhang [2011] extend Miller [2006] to a multi-firm setting. They find that Miller's [2006] finding may not hold once the peer firm’s guidance strategy is considered (see Section 5.3.5).

\subsubsection{Guidance News Valence}


A few studies have examined how the predicted effect varies with guidance news valence (i.e., whether the guidance news is positive or negative, see Table 1). Some studies show that the proposed effect varies symmetrically across positive and negative guidance news domain [e.g., Tan et al., 2002; Libby et al., 2006; Rennekamp, 2012]. By applying mental accounting theory, Tan et al. [2002] show that for positive (negative) guidance news, understating total earnings news in guidance news leads to more positive (negative) reactions than accurate guidance news, which in turn leads to more positive (negative) reactions than overstating total earnings news in guidance news. Libby et al. [2006] show that for positive (negative) total earnings news, narrow range guidance (where the actual EPS exceeds the whole range) leads to more positive (negative) investors' reactions compared with point guidance, whereas wide range guidance (where the actual EPS misses the whole range) leads to less positive (negative) investors' reactions compared with point guidance. Similarly, Rennekamp [2012] shows that compared with less readable disclosure, more readable disclosure leads to more positive (negative) investors' reactions for positive (negative) guidance news.

Some studies show that the proposed effect varies asymmetrically across positive and negative guidance news [Du, 2009; Han and Tan, 2010]. Investors are ambiguity averse (seeking) for negative (positive) guidance news, hence investors favor range (point) guidance when the news is positive [negative; Du, 2009]. Given that positive guidance is inherently less credible (therefore more elastic) than negative guidance, Han and Tan [2010] propose that motivated reasoning is more likely to happen for positive guidance than negative guidance.

\subsubsection{Guidance Forms}

In this section I review studies on how investors react to forms of earnings guidance. Research on guidance forms focuses on comparing point and range guidance [e.g., Hirst et al., 
1999; Libby et al., 2006]. The primary reason for the popularity of point and range guidance in research is the ease with which information can be held constant between them [Hirst et al., 1999]. Researchers normally set the midpoint of range guidance equal to point guidance, and point guidance can thus be viewed as extreme range guidance where the range width is zero [Hirst et al., 1999].

Hirst et al. [1999] suggest that guidance form affects investor confidence, with investors being more confident when management guidance takes the form of more precise point guidance than less precise range guidance. Hirst et al. [1999] suggest, however, that guidance form does not affect investors' earnings estimates. Du [2009] extends Hirst et al. [1999] in two ways. First, Du [2009] shows that although investors' earnings estimates are not affected by guidance form, their resource allocation (investment dollar amount) decision (between a firm issuing point guidance versus a firm issuing range guidance) is affected by guidance form. Second, investors' resource allocation decision depends on whether the guidance news is positive or negative. Specifically, investors prefer ambiguity for positive news but they are ambiguity averse for negative news. Hence investors allocate more resource to the firm issuing range (point) guidance when the news is positive (negative).

More recent research extends Hirst et al. [1999] by documenting that, although investors' post-guidance earnings estimates are not affected by guidance form, their earnings re-estimates after the actual earnings announcement are affected by guidance form [Libby et al., 2006; Han and Tan, 2007]. Libby et al. [2006] show that when the actual earnings are higher (lower) than point guidance (which equals to the midpoint of range guidance), investors' reactions are most positive (negative) for narrow-range guidance (where the actual earnings exceed the high-end of the narrow range), followed by point guidance, then by wide-range guidance (where actual 
earnings are lower than the high-end of the wide range). Han and Tan [2007] corroborates findings of Libby et al. [2006] by proposing and testing a set of multiple-reference-point rules, and comparing point and range guidance with a hybrid guidance form -- MID guidance. ${ }^{5}$ Du et al. [2011] propose a two-stage process to explain investors' preference for point or range management earnings guidance. First, congruity principle [Badescu and Wallsten, 1995] argues that investors prefer a guidance form that is congruent with the environmental uncertainty. Based on this argument, investors prefer point guidance when the environmental uncertainty is very low. Otherwise, investors prefer range guidance. Second, as the range guidance gets wider, it loses informativeness although it is more accurate (i.e., more likely to contain actual EPS). Investors prefer narrow range guidance to wide range guidance due to the informative advantage of narrow range guidance (than wide range guidance). Hence, in most cases, investors prefer narrow range guidance to point guidance and/or wide range guidance.

\subsubsection{Guidance Timing}

Analysts may react differently to EPS guidance issued at different points in time. Libby et al. [2008] show that analysts tend to be more optimistic at earlier points in time than at later points in time due to analysts' incentives to please management, so that it is easier for the actual earnings to meet or beat the analysts’ forecast. Hence analysts are more likely to adjust for any optimistic bias in management guidance if the guidance is provided later but not earlier [Libby et al., 2008]. Libby et al.'s [2008] findings are consistent with findings of archival studies [Richardson et al., 2004]. More importantly, Libby et al. [2008] establish the causal relationship

\footnotetext{
${ }^{5}$ A typical format of MID guidance is, for example, “EPS is expected to be $\$ 1$, plus or minus $\$ 0.1$.”
} 
between analysts' relationship incentives (see page 23) and the optimistic-to-pessimistic pattern in analysts' forecasts. ${ }^{6}$

\subsubsection{Guidance Disaggregation}

The literature documents several benefits of disaggregated guidance to the guider. For example, Hirst et al. [2007] find that for positive guidance news, which is typically less believable than negative guidance news, disaggregated guidance leads investors to perceive higher management credibility (relative to aggregated guidance), hence leads to lower cost of capital, particularly when managers have strong incentives to manipulate earnings. More recent research suggests that such benefits of disaggregated guidance may be limited to point guidance (which is fairly precise), but not to range guidance [which is less precise; Fleming, 2009]. Another benefit with issuing disaggregated guidance is that it reduces investor fixation on net income $^{7}$ [Elliott et al., 2011], because disaggregated guidance facilitates investors' activation of a knowledge structure in which net income is one of several inputs to evaluate company performance, rather than a knowledge structure where net income is the sole sufficient performance measure.

Nevertheless, certain costs (to the guider) are associated with issuing disaggregated guidance. Disaggregated guidance makes it more difficult for managers to hide earnings manipulation activities, because more detailed and specific guidance restrict managers' ways to maneuver earnings results [Holderness and Hunton, 2011].

\footnotetext{
${ }^{6}$ Optimistic-to-pessimistic pattern refers to the observation that analysts' early earnings forecasts are usually optimistic, then analysts gradually "walk down" their earnings forecasts, until the forecasts become pessimistic (so that the actual EPS is able to meet or beat analysts' forecasts) when it comes to the actual earnings announcement date [Richardson et al., 2004].

7 Investors' earnings fixation refers to investors' tendency to over rely on the bottom-line earnings figure while neglect other relevant information [Elliott et al., 2011].
} 


\subsubsection{Sensitivity Analysis}

Future earnings results are sometimes subject to the influence of factors beyond management control. For example, an airline company’s earnings are affected by oil prices, and the general interest rate environment affects a financial company's performance. It is common practice for firms to disclose future earnings sensitivity to such external, uncontrollable factors. Koonce et al. [2005] examine how investors respond to one-sided loss-only sensitivity disclosure, which is mandated under current accounting standards (SEC Financial Reporting Release No. 48). Koonce et al. [2005] indicate that investors likely infer a smaller amount of potential gain than the disclosed loss amount. However, such inference corresponds to the company using a fairly infrequent risk management strategy. Nelson and Rupar [2011] study whether investor risk assessment is affected by numerical disclosure versus percentage disclosure for potential downside risk. Nelson and Rupar [2011] find that numerical disclosure leads to higher risk assessment compared with percentage disclosure, but only when the disclosure format is mandatory rather than discretionary. Investors subconsciously anchor on the bigger number (compared with percentage) and therefore infer higher risk. They reason that when managers have discretion over numerical versus percentage disclosure, investors may view a percentage disclosure as the manager's attempt to understate downside risk, which investors counter-react by raising their risk assessment.

\subsubsection{Narrative Disclosures}

Disaggregated earnings guidance and sensitivity analysis both relate to quantitative information contained in management earnings guidance. Another stream of research examines the narrative words used in management earnings guidance (i.e., narrative disclosure). Several dimensions of narrative disclosure have been examined in the literature. 
Scenario construction. Sedor [2002] finds that analysts are subject to "scenario thinking;" wherein a manager's earnings guidance is assessed to have a higher probability of being realized if it is described in a scenario than if it is provided in a simple list of facts. ${ }^{8}$ Sedor's [2002] findings compliment archival research on analyst optimism in earnings guidance where it is usually suggested that analyst optimism is solely driven by their incentive to please management [Cowen et al., 2006]. However, Sedor [2002] suggests that such optimism can be an unintentional cognitive bias rather than a result of any economic or business incentive. Kadous et al. [2006] extend Sedor [2002] by investigating how to reduce analyst optimism induced by scenario thinking. Drawing from psychology literature, Kadous et al. [2006] suggest that asking analysts to provide reasons why managers could fail (“counter-explanations”) may reduce the effect of scenario thinking, but only if it is easy to generate the counter-explanations (e.g., asking analysts to generate 2 counter-explanations compared to 12 counter-explanations).

Readability. Readability refers to the ease with which text can be read and understood [Tan et al., 2012, p. 7]. Rennekamp [2012] examines how readability of the guidance press release affects investors' reactions. Rennekamp [2012] finds that investors' reactions are more extreme (i.e., more negative for negative guidance and more positive for positive guidance) in response to more readable disclosures. Tan et al. [2012] suggest that more readable disclosures are associated with higher management credibility, but this effect is stronger when the message content is inconsistent (e.g., actual earnings beat one benchmark but miss the other) than when the message content is consistent (e.g., actual earnings consistently beat multiple benchmarks). The implication is that message delivering (here, readability) does not matter so much when

\footnotetext{
${ }^{8}$ Managers can construct a scenario by vividly describing the events, or providing the causal links of facts, etc. For example, the following sentence is a scenario description - "The strong economy and the publicity given to the health benefits of moderate wine consumption continue to fuel consumer demand for wine. In fact, industry-wide sales of red wine have more than doubled in the past few years." A corresponding list of facts would be: 1 . Industry wide sales of red wine have more than doubled in past few years; 2. Strong economy [Sedor, 2002, p. 748 and 749].
} 
message content is clear-cut; however, message delivering is crucial if message content is arguable.

Vividness. Vivid language is “(a) emotionally interesting; (b) concrete and imageryprovoking, and (c) proximate in a sensory, temporal, or spatial way,” while pallid language is “more bland, sterile, or less emotionally charged” [Hales et al., 2011, p. 224]. Hales et al. [2011] show that vivid presentation tends to influence investors who hold contrarian positions (i.e., short investors in a bull market or long investors in a bear market), but the influence is less for investors who hold momentum positions (i.e., long investors in a bull market or short investors in a bear market). Interestingly, vivid presentation alleviates contrarian investors' bias in interpreting news rather than deepening momentum investors’ bias in interpreting news, contrary to common belief in practice.

Narrative words can vary in multiple dimensions and there is usually no database maintained on narrative disclosures, hence it is difficult for archival researchers to conduct meaningful research on narrative disclosures (see Li [2010] for a review of archival studies on textual disclosures). Experimental researchers are able to make unique contribution in this area because of their ability to hold constant other dimensions of language while varying only one interested dimension in their studies [Libby et al., 2002]. Experimental research provides very important supplements to archival findings in this area.

\subsection{Guider or Environmental Attributes}

This section analyzes the literature on how guider characteristics and/or environment attributes affect investors' reactions to management earnings guidance, including guider's incentives to manage earnings, guider's prior earnings record, analyst incentives, investors' 
investment positions, peer company guidance strategy, operating environment uncertainty, and finally regulatory environment.

\subsubsection{Guider's Incentives to Manage Earnings}

Several studies examine how managers’ incentives to manage earnings interact with other factors to affect investors' reactions to earnings guidance. Hirst et al. [2007] show that investors take managers' incentives to manage earnings into account when they evaluate the credibility of earnings guidance. Hirst et al. [2007] compare the credibility of aggregated versus disaggregated earnings guidance. For an aggregated guidance, investors perceive that the guidance is more credible when managerial compensation consists only of fixed salary (therefore low incentives to manipulate earnings) than when it consists largely of performance-based pay (therefore high incentives to manipulate earnings). One measure to improve the perceived credibility of earnings guidance is to provide disaggregated earnings guidance. Disaggregated earnings guidance reduces managers’ opportunities to meet their guided earnings through earnings management, therefore investors perceive higher financial reporting quality for firms providing disaggregated guidance (albeit the management has high incentive to manipulate earnings).

\subsubsection{Guider's Prior Earnings Record}

Investors’ reactions to current earnings guidance may differ systematically between firms with prior profits versus losses. Analysts and investors assume that prior losses are less persistent than prior profits and hence are more motivated to rely on other relevant information (here, management guidance) when predicting future earnings for prior-loss firms than for prior-profit firms [Sedor, 2002]. 


\subsubsection{Analyst Incentives}

Analysts desires to have more accurate earnings forecasts since higher accuracy in earnings forecasts means better reputation and brighter career future [Brown, 2001]. Other than an incentive to provide accurate guidance, analysts may sometimes have incentives to maintain a good relationship with managers to generate business opportunities and/or gain access to management information [i.e., "relationship incentives;” Schipper, 1991]. The relationship incentives have been found to partly contribute to the observed optimistic-to-pessimistic pattern in analyst forecasts [Libby et al., 2008]. When analysts are provided with pessimistically biased earnings guidance, analysts with relationship incentives (compared with analysts with accuracy incentives) are more reluctant to adjust for such bias in manager earnings guidance. Their earnings forecasts tend to follow the downward biased pattern so that it is easy for the actual EPS to meet or beat the analysts’ forecasts [Tan et al., 2010].

\subsubsection{Investors' Investment Positions}

Investment positions (i.e., whether long-holding or short-selling a stock) may affect investors' reactions to earnings guidance. Motivated reasoning theory suggests that investors are more likely to interpret earnings guidance with a bias toward a gain rather than a loss [Hales, 2007]. For example, long (short) investors tend to evaluate the same EPS guidance more optimistically (pessimistically), since long (short) investors make a gain if stock price appreciates (depreciates). Han and Tan [2010] show that such an effect can occur only when there is enough elasticity in the news (i.e., when there is room for investors to maneuver their evaluation). Positive guidance is less credible than negative guidance given managers' incentives to announce positive news [Lang and Lundholm, 2000]. Hence positive guidance is more elastic than negative guidance. Range guidance offers a range of possible future earnings, whereas point 
guidance offers only one expected point EPS. Hence range guidance is more elastic than point guidance. Han and Tan [2010] find that investors are more likely to engage in motivated reasoning for positive guidance (compared with negative guidance) or for range guidance (compared with point guidance). Hales et al. [2011] suggest that investors are more sensitive to preference-inconsistent news than to preference-consistent news. Hales et al. [2011] demonstrate that investors react more strongly to vivid language than to pallid language, but this effect holds only for preference-inconsistent news (i.e., long/short investors reading negative/positive news) and not for preference-consistent news (i.e., long/short investors reading positive/negative news).

\subsubsection{Peer Company Guidance Strategy}

Maletta and Zhang [2011] suggest that investors' reaction to a firm's earnings guidance is dependent on the earnings guidance strategy of a peer firm. In particular, Maletta and Zhang [2011] investigate the effect of a firm's relative guidance news surprise (i.e., how positive or negative the firm's earnings guidance news is relative to peer firm earnings guidance news). They find that when the two firms release a similar percentage of guidance news to total earnings news, Miller's [2006] finding continues to hold (i.e., investor earnings estimates are highest when guidance news equals half of total earnings news compared with scenarios of releasing guidance news that comprises $25 \%$ or $75 \%$ of total earnings news). However, when the two firms differ in terms of percentage of total earnings news released in guidance news, investors' reactions to firm earnings guidance increase as the percentage released by the firm relative to its peer firm increases. Maletta and Zhang's [2011] paper is an example of how guidance characteristics and environmental factors sometimes interplay to affect investors' reactions to earnings guidance. 


\subsubsection{Operating Environment Uncertainty}

Rupar [2011] suggests that investors consider a firm’s operating environment uncertainty when reacting to earnings guidance. Rupar [2011] introduces investors' ex ante expectations induced from environmental uncertainty as a factor and examines its joint effect with guidance form on investor earnings estimates. Rupar [2011] finds that investors' earnings estimates (as well as their assessments of management credibility) are higher when guidance precision and investor expectations are aligned (precise/less precise guidance form with low/high environmental uncertainty) than when they are not aligned (less precise/precise guidance form with low/high environmental uncertainty). Du et al. [2011], similarly, call for matching earnings guidance precision with information uncertainty. More (less) precise guidance form should be used when information uncertainty is low (high).

\subsubsection{Regulatory Environment}

Research shows that investors consider the regulatory environment when reacting to management disclosures. When the disclosure format is mandated, investors perceive little room for managers to manipulate it and therefore are less vigilant to manager's strategic disclosure. In contrast, when the disclosure format is voluntary, investors are vigilant to managers' attempt to manipulate the disclosure format and therefore try to counteract the effect of this manipulation [Nelson and Rupar, 2011].

\section{EFFECT OF MANAGEMENT GUIDANCE ON GUIDER BEHAVIOR}

Guidance frequency may affect manager operating activity decisions because of managers' consideration on the implication of any operating decisions on earnings [since more frequent guidance imposes more benchmarks to evaluate actual earnings; Bhojraj and Libby, 2005]. Wang and Tan [2013] show that a frequent guider tends to sacrifice total long-term 
earnings to meet short-term earnings targets. That is, a frequent guider is more likely to choose an operating strategy with lower total expected earnings but higher earnings predictability over the other strategy with higher total expected earnings but lower earnings predictability.

Management myopic behavior refers to management tendency to sacrifice long-term earnings growth in order to meet short-term earnings targets [Cheng et al., 2005]. Bhojraj and Libby [2005] suggest that increased disclosure frequency (quarterly reporting versus semiannual reporting) induces management myopia. Similarly, more frequent guidance (compared with less frequent guidance) also leads to lower research and development investment and therefore lower long-term earnings growth rate [Cheng et al., 2005]. The concern of management myopia has led to recent calls to stop short-term earnings guidance while focusing on disclosure of long-term strategies and goals [Hsieh et al., 2006]. Clearly, management should weigh the benefits and costs of issuing guidance (especially short-term guidance) and any implications of issuing guidance on their operating decisions [Diamond and Yevmenenko, 2011].

Insert Table 1 Here

Table 1 summarizes the theory, main independent variables, main dependent variables, and key research findings of the papers reviewed in Section 4 to Section 6 .

\section{FUTURE RESEARCH DIRECTIONS AND CONCLUSIONS}

In this section, I suggest several potential areas for future research based on the literature review above and offer concluding remarks. 


\subsection{Managers’ Personal Attributes}

The literature thus far has little to say regarding the extent to which managers’ personal attributes affect their earnings guidance behavior [Libby and Rennekamp, 2012]. As a result, there is considerable room for additional research to explore the effect of managers' personal attributes on their earnings guidance decisions [Brochet et al., 2011]. Based on a small-scale review on literature of CEO personal attributes, I offer the following possible future research avenues.

\subsubsection{CEO Demographics}

Several studies have shown that overconfident managers are more likely to issue earnings guidance [than less overconfident managers; e.g., Hilary and Hsu, 2011; Libby and Rennekamp, 2012]. Psychology research has demonstrated that several demographic characteristics are associated with overconfidence; such as age, gender, years of experience, and political preferences [e.g., Barber and Odean, 2001]. In particular, psychology research has documented mixed findings regarding the effect of age on overconfidence. Some research suggests young people are more overconfident than old people [Pliske and Mutter, 1996] while others suggest the opposite [e.g., Job, 1990]. Future research may examine the effect of the CEO's age on earnings guidance behavior and whether this effect is via overconfidence.

A recent working paper [Hutton et al., 2013] suggests that Republican managers (compared with Democratic managers) are more conservative in corporate policies (for instance,

republican managers take on lower debt level and lower R\&D expenses). Future research may investigate the effect of manager's political ideology on their guidance behavior.

\subsubsection{CEO Self-Monitoring}


Self-monitoring refers to a person's sensitivity to other people’s comments and therefore his/her own reputation [Seybert, 2010]. Seybert [2010] finds that high self-monitoring managers are more likely to over-invest in R\&D projects than low self-monitoring managers. Prior studies show that the desire for a better reputation is one of the reasons for managers to provide guidance [Graham et al., 2005; Hirst et al., 2008]. Future research may examine whether high self-monitoring managers (i.e., those managers who are more likely to alter their behaviors in order for a better image) are more likely to issue earnings guidance.

\subsubsection{CEO Narcissism}

Narcissists believe that they are better than most others for almost every task [Resick et al., 2009]. Olsen [2011] demonstrates that Narcissist CEOs tend to report higher EPS. Future research may investigate whether Narcissist CEOs are more likely to issue earnings guidance and in particular, if their earnings guidance is more optimistic (than non-Narcissist CEOs' guidance).

\subsection{Guidance Characteristics}

\subsubsection{Earnings Guidance Attributions}

Research on guidance content thus far largely examines quantitative information accompanying earnings guidance (e.g., disaggregated earnings guidance or sensitivity analysis). However, earnings guidance also often includes qualitative information [e.g., manager explanations as to why future earnings are predicted to be better or worse; Hutton et al., 2003; Baginski et al., 2004]. Experimental research has investigated attribution effects in other contexts, such as earnings restatements [Elliott et al., 2012] and management discussion and analysis [Barton and Mercer, 2005; Koonce et al., 2012]. Barton and Mercer [2005] find that analysts are able to differentiate plausible versus implausible explanations offered by managers for a poor earnings result, and they think more positively on a firm providing plausible attributions for their 
earnings results (compared with a firm with implausible attributions). Elliott et al. [2012] show that investors have greater trust in managers who accept responsibility for earnings restatements than in those who deny responsibility, and this difference is enlarged by an online restatement compared to a paper restatement. Koonce et al. [2012] express concern that investors may not be able to attend to the completeness of management explanations. Future research might examine attribution effects in the earnings guidance context and thereby complement archival research in this area [Rupar, 2011].

\subsubsection{Guidance Forms}

Extant experimental research on guidance forms has focused primarily on point or range guidance with relatively less emphasis on examining other guidance forms, such as minimum, maximum, and qualitative guidance. Nevertheless, the literature indicates that minimum and maximum guidance is significant in practice, accounting for $68.2 \%$ of the sample in Pownall et al. [1993], and 33\% in Baginski et al. [2011]. In the context of contingent environmental liability disclosure, Kennedy et al. [1998] compare minimum and maximum estimates with best estimates and range estimates. Kennedy et al. [1998] find that investors tend to anchor on the numbers provided and generate ranges of estimated environmental liability that are too narrow. Further, investor risk assessments are significantly higher for a maximum environmental liability disclosure than for a minimum disclosure. Future research may investigate whether the results of Kennedy et al. [1998] generalize to the earnings guidance setting where the financial figures involved are much smaller in scale, or whether other variables moderate the effect of different guidance forms.

Qualitative guidance accounts for a non-trivial percentage in earnings guidance as well. Qualitative guidance is 7.8\% within the sample in Bamber and Cheon [1998]. Again, research on 
qualitative guidance is rather limited [one exception is Libby and Tan, 1999]. Thus, future research examining the nature and effect of qualitative guidance will be productive.

\subsubsection{Guidance Media}

Managers may provide earnings guidance orally in earnings conference calls or in written form published in press releases [Bamber and Cheon, 1998]. Thus far, experimental research on management earnings guidance has been conducted in written format, be it on paper or electronically. Elliott et al. [2012] find that investor trust in management is higher (lower) when the manager accepts (denies) responsibility for earnings restatements via online video announcements, compared with text announcements. Future research may investigate how investors' reactions differ for the same earnings guidance issued in different media formats. Based on the findings of Elliott et al. [2012], evaluations of manager personal attributes, such as credibility (competence and integrity), are particularly subject to media effects.

\subsubsection{Confirming Management Guidance}

For those studies that examine investors' reactions to management guidance, almost all involve positive or negative guidance news. However, as indicated by Clement et al. [2003], approximately $19 \%$ of their total guidance sample for the 1993-1997 period relates to confirming guidance (i.e., there is neither a positive nor a negative surprise in the earnings guidance-management issues the guidance to confirm current market expectations). Future research may consider studying the phenomenon of confirming guidance directly, by comparing it with positive or negative guidance or indirectly, by studying its joint effect with other guidance/guider characteristics and/or environmental factors. For example, it would be interesting to determine whether the documented effects of disaggregated earnings guidance generalize to confirming guidance. 


\subsection{Environmental Attributes}

\subsubsection{Multi Period and/or Multi-Firm Settings}

Most studies reviewed in this paper consider a single-period, single-firm scenario. In practice, however, management earnings guidance is a repetitive decision and investors' reactions are affected not only by a firm's own disclosure strategy, but also by the disclosure strategy of its peer firms. For instance, Miller [2006] documents that investors react more positively when the total earnings news is split equally between guidance news and actual earnings news, than when the total earnings news is divided into one piece of large news and one piece of small news. However, Maletta and Zhang [2011] show that the conclusion of Miller [2006] holds only when there is no contrast between the disclosure strategies of the target firm and its peer firm; when there is such a contrast (e.g., the percentage of total earnings news released in guidance news differs), investors focus on the target firm in comparison with its peer firm, rather than on the target firm in isolation. Researchers should incorporate this multi-firm, multi-period setting into their experimental designs to increase the external validity of their studies. Future research could also test whether findings documented in a single-firm, singleperiod setting generalize to multi-firm and/or multi-period settings.

\subsubsection{Regulatory Environment}

Experimental studies have the unique advantage of creating a regulatory environment in the lab which may not exist in the real world, and being able to compare and contrast management and/or investor behaviors under existing versus proposed regulations [Bhojraj and Libby, 2005; Nelson and Rupar, 2011]. Management earnings guidance is voluntary disclosure where very few regulations are in existence [Hirst et al., 2008]. Experimental researchers may 
utilize their methodological advantages and continue to make contributions to policy research in the area of management earning guidance [Maines, 1994].

\subsection{The Effect of Management Guidance on Guider's Behavior}

There is little research on whether and how managers’ operating and/or other disclosing decisions are affected by their earnings guidance strategies (see Holderness and Hunton [2011] and Wang and Tan [2013] as exceptions). Future research may study how managers’ operating and disclosing decisions are affected by managers’ earnings guidance behavior.

\subsection{Conclusions}

This paper reviews experimental research on management earnings guidance. First, I review guider and environmental attributes that may affect management earnings guidance decisions. Next, I review whether and how investors react differently to management guidance characteristics, which sometimes jointly work with guider attributes and/or environmental attributes. Finally, I review how management earnings guidance behavior may affect their operating and disclosing decisions. Based on my literature synthesis, I also offer my views on promising future research directions. 


\section{REFERENCES}

Ajinkya, B. B. and M. J. Gift. 1984. Corporate managers' earnings forecasts and symmetrical adjustments of market expectations. Journal of Accounting Research 22 [2]: 425-444.

Baginski, S. P., and J. M. Hassell. 1990. The market interpretation of management earnings forecasts as a predictor of subsequent financial analyst forecast revision. The Accounting Review 65 [1]: 175-190.

Baginski, S. P., J. M. Hassell, and M. D. Kimbrough. 2004. Why do managers explain their earnings forecasts? Journal of Accounting Research 42 [1]: 1-29.

Baginski, S. P., J. M. Hassell, and M. M. Wieland. 2011. An examination of the effects of management earnings forecast form and explanations on financial analyst forecast revisions. Advances in Accounting 27: 17-25.

Bamber, L. S., and Y. S. Cheon. 1998. Discretionary management earnings forecast disclosures: Antecedents and outcomes associated with forecast venue and forecast specificity choices. Journal of Accounting Research 36 [2]: 167-190.

Barber, B. M., and T. Odean. 2001. Boys will be boys: Gender, overconfidence, and common stock investment. The Quarterly Journal of Economics 116 [1]: 261-292.

Barton, J., and M. Mercer. 2005. To blame or not to blame: Analysts' reactions to external explanations for poor financial performance. Journal of Accounting and Economics 39 [3]: 509-533.

Bhojraj, S., and R. Libby. 2005. Capital market pressure, disclosure frequency-induced earnings/cash flow conflict, and managerial myopia. The Accounting Review 80 [1]: 1-20.

Bhojraj, S., R. Libby, and H. Yang. 2012. Guidance frequency and guidance properties: The effect of reputation-building and learning-by-doing. Working paper, Cornell University and University of Pennsylvania.

Brochet, F., L. Faurel, and S. McVay. 2011. Manager-specific effects on earnings guidance: An analysis of top executive turnovers. Journal of Accounting Research 49 [5]: 1123-1162.

Brown, L. D. 2001. How important is past analyst forecast accuracy? Financial Analysts Journal 57 [6]: 44-49.

Cameron, A. B. 1986. A review of management's earnings forecast research. Journal of Accounting Literature 5: 57-83.

Cheng, M., K. R. Subramanyam, and Y. Zhang. 2005. Earnings guidance and managerial myopia. Working paper, University of Arizona, University of Southern California, and Columbia University. 
Clement, M., R. Frankel, and J. Miller. 2003. Confirming management earnings forecasts, earnings uncertainty, and stock returns. Journal of Accounting Research 41 [4]: 653-679.

Cowen, A., B. Groysberg, and P. Healy. 2006. Which types of analyst firms are more optimistic? Journal of Accounting and Economics 41 [1-2]: 119-146.

Degeorge, F., J. Patel, and R. Zeckhauser. 1999. Earnings management to exceed thresholds. Journal of Business 72 [1]: 1-33.

Diamond, C. J., and I. Yevmenenko. 2011. Earnings releases and earnings calls. Practical Law Journal 2011 [October]: 34-44.

Du, N. 2009. Do investors react differently to range and point management earnings forecasts? The Journal of Behavioral Finance 10 [4]: 195-203.

Du, N., D. V. Budescu, M. K. Shelly, and T. C. Omer. 2011. The appeal of vague financial forecasts. Organizational Behavior and Human Decision Processes 114 [2]: 179-189.

Elliott, W. B., J. L. Hobson, and K. E. Jackson. 2011. Disaggregating management forecasts to reduce investors' susceptibility to earnings fixation. The Accounting Review 86 [1]: 185-208.

Elliott, W. B., F. D. Hodge, J. J. Kennedy, and M. Pronk. 2007. Are M.B.A. students a good proxy for nonprofessional investors? The Accounting Review 82 [1]: 139-168.

Elliott, W. B., F. Hodge, and L. M. Sedor. 2012. Using online video to announce a restatement: Influences on investment decisions and the mediating role of trust. The Accounting Review 87 [2]: 513-535.

Fleming, D. M. 2009. Management forecast characteristics: Effects on venture capital investment screening judgments. Behavioral Research in Accounting 21 [2]: 13-36.

Fuller, J., and M. C. Jensen. 2010. Just say no to Wall Street: Putting a stop to the earnings game. Journal of Applied Corporate Finance 22 [1]: 59-63.

Graham, J., C. R. Harvey, and S. Rajgopal. 2005. The economic implications of corporate financial reporting. Journal of Accounting and Economics 40 [1]: 3-73.

Hales, J. 2007. Directional preferences, information processing, and investors' forecasts of earnings. Journal of Accounting Research 45 [3]: 607-628.

Hales, J., X. J. Kuang, and S. Venkataraman. 2011. Who believes the hype? An experimental examination of how language affects investor judgments. Journal of Accounting Research 49 [1]: 223-255. 
Han, J., and H-T. Tan. 2007. Investors' reactions to management guidance forms: The influence of multiple benchmarks. The Accounting Review 82 [2]: 521-543.

Han, J., and H-T. Tan. 2010. Investors' reactions to management earnings guidance: The joint effect of investment position, news valence, and guidance form. Journal of Accounting Research 48 [1]: 81-104.

Hilary, G., and C. Hsu. 2011. Endogenous overconfidence in managerial forecasts. Journal of Accounting and Economics 51 [3]: 300-313.

Hirst, D. E., L. Koonce, and J. Miller. 1999. The joint effect of management's prior forecast accuracy and the form of its financial forecast on investor judgment. Journal of Accounting Research 37 [Supplement]: 101-124.

Hirst, D. E., L. Koonce, and S. Venkataraman. 2007. How disaggregation enhances the credibility of management earnings forecasts. Journal of Accounting Research 45 [4]: 811837.

Hirst, D. E., L. Koonce, and S. Venkataraman. 2008. Management earnings forecasts: A review and framework. Accounting Horizons 22 [3]: 315-338.

Hogarth, R. M., and H. J. Einhorn. 1992. Order effects in belief updating: The belief adjustment model. Cognitive Psychology 24 [1]: 1 -55.

Holderness Jr., D. K., and J. E. Hunton. 2011. Obfuscating earnings management when issuing disaggregated earnings guidance. Working paper, Bentley University.

Hribar, P., and H. Yang. 2011. CEO overconfidence and management forecasting. Working paper, University of Iowa and University of Pennsylvania.

Hsieh, P., T. Koller, and S. R., Rajan. 2006. The misguided practice of earnings guidance. McKinsey Quarterly [Spring]: 1-12.

Hughes, J., and S. Pae. 2004. Voluntary disclosure of precision information. Journal of Accounting and Economics 37 [2]: 261-289.

Hutton, A. P., G. S. Miller, and D. J. Skinner. 2003. The role of supplementary statements with management earnings forecasts. Journal of Accounting Research 41 [5]: 867-890.

Hutton, I., D. Jiang, and A. Kumar. 2013. Corporate policies of Republican managers. Working paper, Florida State University and University of Miami.

Job, R.S. 1990. The application of learning theory to driving confidence: The effect of age and the impact of random breath testing” Accident Analysis \& Prevention 22: 97-107.

Kadous, K., S. D. Krische, and L. M. Sedor. 2006. Using counter-explanation to limit analysts' forecast optimism. The Accounting Review 81 [2]: 377-397. 
Kasznik, R., and B. Lev. 1995. To warn or not to warn: Management disclosures in the face of an earnings surprise. The Accounting Review 70 [1]: 113-134.

Kennedy, J., T. Mitchell, and S. E. Sefcik. 1998. Disclosure of contingent environmental liabilities: Some unintended consequences? Journal of Accounting Research 36 [2]: 257-277.

King, R. R., G. Pownall, and G. Waymire. 1990. Expectations adjustments via timely management forecasts: Review, synthesis, and suggestions for future research. Journal of Accounting Literature 9: 113-144.

Koonce, L., M. G. Lipe, and M. L. McAnally. 2005. Judging the risk of financial instruments: Problems and potential remedies. The Accounting Review 80 [3]: 871-895.

Koonce, L., N. Seybert, and J. Smith. 2012. Management speaks, investors listen: Are investors too focused on managerial disclosures? Working paper, The University of Texas at Austin and University of Maryland.

Lang, M. H., and R. J. Lundholm. 2000. Voluntary disclosure and equity offerings: Reducing information asymmetry or hyping the Stock? Contemporary Accounting Research 17 [4]: 623-662.

Li, F. 2010. Textual analysis of corporate disclosures: A survey of the literature. Journal of Accounting Literature 29: 143-165.

Libby, R., R. Bloomfield, and M. Nelson. 2002. Experimental research in financial accounting. Accounting, Organizations and Society 27 [8]: 775-810.

Libby, R., J. E. Hunton, H-T. Tan, and N. Seybert. 2008. Relationship incentives and the optimistic/pessimistic pattern in analysts' forecasts. Journal of Accounting Research 46 [1]: 173-198.

Libby, R., and K. Rennekamp. 2012. Self-serving attribution bias, overconfidence and the issuance of management forecasts. Journal of Accounting Research 50 [1]: 197-231.

Libby, R., and H-T. Tan. 1999. Analysts' reactions to warnings of negative earnings surprises. Journal of Accounting Research 37 [2]: 415-435.

Libby, R., H-T. Tan., and J. E. Hunton. 2006. Does the form of management's earnings guidance affect analysts’ earnings forecasts? The Accounting Review 81 [1]: 207-225.

Maines, L. A. 1994. The role of behavioral accounting research in financial accounting standard setting. Behavioral Research in Accounting 6 [supplement]: 204-212.

Maletta, M. J., and Y. M. Zhang. 2011. Investor reactions to contrasts between the earnings preannouncements of peer firms. Contemporary Accounting Research 29 [2]: 361-381. 
Mercer, M. 2005. The fleeting effects of disclosure forthcomingness on management's reporting credibility. The Accounting Review 80 [2]: 723-744.

Miller, J. S. 2006. Unintended effects of preannouncements on investor reactions to earnings news. Contemporary Accounting Research 23 [4]: 1073-1103.

Nelson, M. W., and K. Rupar. 2011. Numerical formats within risk disclosures and the moderating effect of investors' disclosure management concerns. Working paper, Cornell University and University of Florida.

Olsen, K. J. 2011. CEO narcissism and accounting: A picture of profits. Working paper, University of Southern California.

Pliske, R.M., and S.A. Mutter . 1996. Age differences in the accuracy of confidence judgments. Experimental Aging Research 22: 199 - 216.

Pownall, G., C. Wasley, and G. Waymire. 1993. The stock price effects of alternative types of management earnings forecasts. The Accounting Review 68 [4]: 896-912.

Rennekamp, K. 2012. Processing fluency and investors' reactions to disclosure readability. Journal of Accounting Research 50 [5]: 1319-1354.

Resick, C. J., D. S. Whitman, S. M. Weingarden, and N. J. Hiller. 2009. The bright-side and the dark-side of CEO personality: Examining core self-evaluations, narcissism, transformational leadership, and strategic influence. Journal of Applied Psychology 94 [6]: 1365-1381.

Richardson, S., S.H. Teoh, and P. D. Wysocki. 2004. The walk-down to beatable analyst forecasts: The role of equity issuance and insider trading incentives. Contemporary Accounting Research 21 [4]: 885-924.

Rogers, J. L., and A. V. Buskirk. 2013. Bundled forecasts in empirical accounting research. Journal of Accounting and Economics 55 [1]: 43-65.

Rupar, K. 2011. Significance of forecast precision: The importance of ex-ante expectations. Working paper, University of Florida.

Schipper, K. 1991. Commentary on analysts’ forecasts. Accounting Horizons 5: 105-121.

Sedor, L. M. 2002. An explanation for unintentional optimism in analysts’ earnings forecasts. The Accounting Review 77 [4]: 731-753.

Seybert, N. 2010. R\&D capitalization and reputation-driven real earnings management. The Accounting Review 85 [2]: 671-693. 
Slovic, P. 1966. Cue-consistency and cue-utilization in judgment. American Journal of Psychology 79 [3]: 427-34.

Tan, H-T., R. Libby, and J. E. Hunton. 2002. Analysts' reactions to earnings preannouncement strategies. Journal of Accounting Research 40 [March]: 223-246.

Tan, H-T., R. Libby, and J. E. Hunton. 2010. When do analysts adjust for biases in management guidance? Effects of guidance track record and analysts' incentives. Contemporary Accounting Research 27 [1]: 187-208.

Tan, H-T., E. Y. Wang, and B. Zhou. 2012. How does readability influence investors' judgments? Consistency of benchmark performance matters. Working paper, Nanyang Technological University, University of Massachusetts Amherst and Shanghai University of Finance and Economics.

Tan, S. K., and L. Koonce. 2011. Investors' reactions to retractions and corrections of management earnings forecasts. Accounting, Organizations, and Society 36 [6]: 386-397.

Thaler, R. H. 1999. Mental accounting matters. Journal of Behavioral Decision Making 12 [3]: 183-206.

Venkataraman, S. 2008. The joint impact of commitment to disclosure and prior forecast accuracy on managers' forecasting credibility. Working paper, Georgia Technology University.

Wang, E. Y., and H-T. Tan. 2013. The effects of guidance frequency and guidance goal on managerial decisions. Journal of Accounting Research 51 [3]: 673-700. 


\section{Figure 1 A Synthesis Framework}

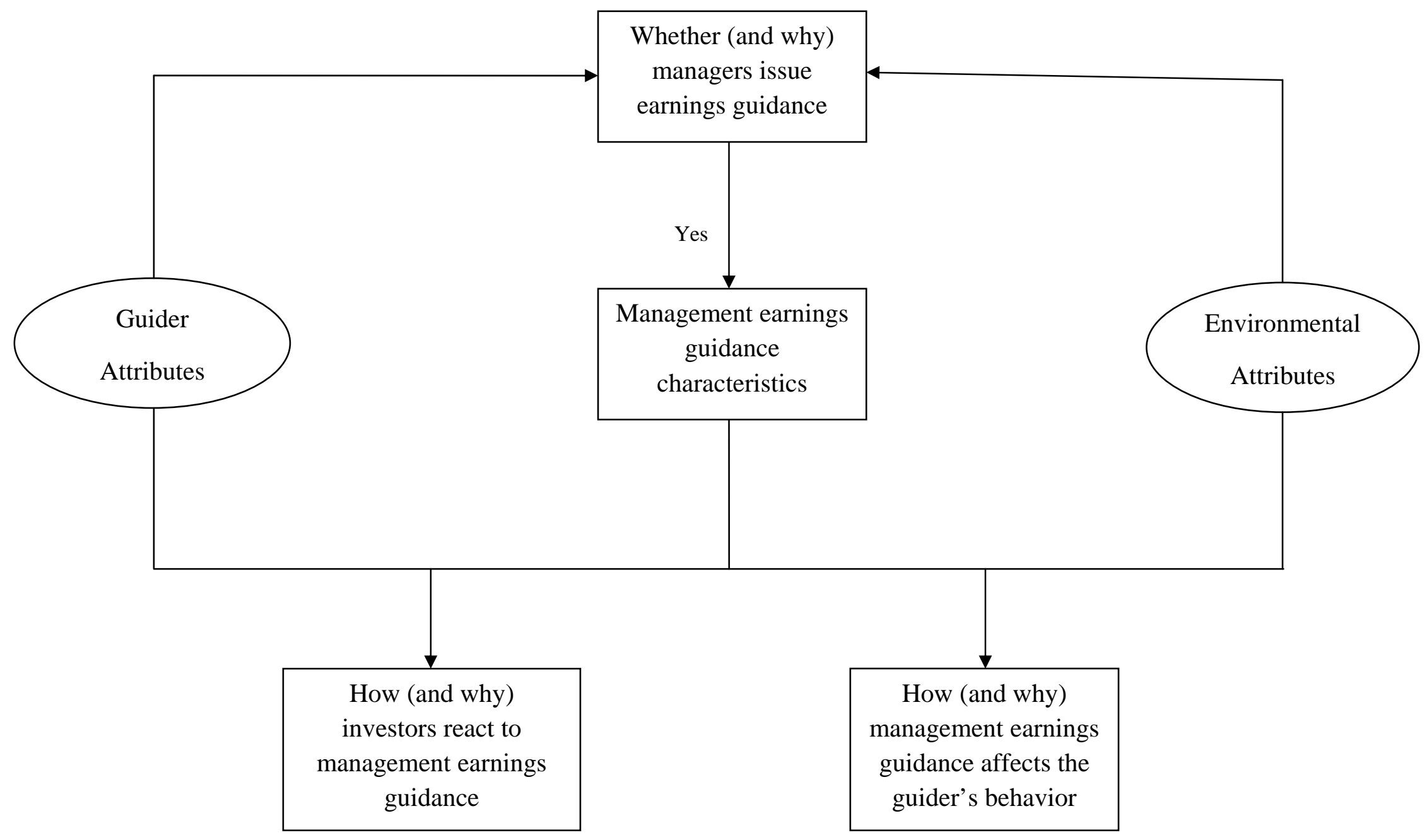


Table 1 Key Research Findings ${ }^{1}$

\begin{tabular}{|c|c|c|c|c|}
\hline Article & Theory & $\begin{array}{c}\text { Main } \\
\text { Independent Variables }\end{array}$ & $\begin{array}{c}\text { Main } \\
\text { Dependent } \\
\text { Variables } \\
\end{array}$ & Key Research Findings \\
\hline $\begin{array}{l}\text { Hirst, } \\
\text { Koonce, } \\
\text { and Miller } \\
\text { [1999, } \\
\text { JAR }^{2}\end{array}$ & $\begin{array}{l}\text { Source } \\
\text { credibility }\end{array}$ & $\begin{array}{l}\text { Prior guidance accuracy } \\
\text { (high, low) } \\
\text { Guidance form (point, } \\
\text { range) }\end{array}$ & $\begin{array}{l}\text { Investors' } \\
\text { confidence and } \\
\text { dispersion in } \\
\text { earnings } \\
\text { estimates }\end{array}$ & $\begin{array}{l}\text { For guidance with inaccurate prior record, } \\
\text { guidance form does not matter; for guidance } \\
\text { with accurate prior record, investor } \\
\text { confidence (dispersion) is higher (lower) for } \\
\text { point guidance than for range guidance. }\end{array}$ \\
\hline $\begin{array}{l}\text { Libby and } \\
\text { Tan } \\
\text { [1999, } \\
\text { JAR] }\end{array}$ & $\begin{array}{l}\text { Cue } \\
\text { consistency }\end{array}$ & $\begin{array}{l}\text { Guidance issuance (no } \\
\text { guidance, sequential } \\
\text { guidance, simultaneous } \\
\text { guidance) }\end{array}$ & $\begin{array}{l}\text { Earnings re- } \\
\text { estimates after } \\
\text { actual earnings } \\
\text { announcement }\end{array}$ & $\begin{array}{l}\text { Analysts' earnings re-estimates are lowest in } \\
\text { sequential processing condition, followed by } \\
\text { no guidance condition, then by simultaneous } \\
\text { processing condition. }\end{array}$ \\
\hline $\begin{array}{l}\text { Sedor } \\
\text { [2002, } \\
\text { TAR] }\end{array}$ & $\begin{array}{l}\text { Scenario } \\
\text { thinking }\end{array}$ & $\begin{array}{l}\text { Information structure } \\
\text { (list, scenario) } \\
\text { Prior earnings (loss, } \\
\text { profit) }\end{array}$ & $\begin{array}{l}\text { Earnings } \\
\text { estimates after } \\
\text { management } \\
\text { guidance }\end{array}$ & $\begin{array}{l}\text { Analysts' earnings estimates are more } \\
\text { optimistic where management plan is } \\
\text { presented as a scenario than as an } \\
\text { unstructured list, and the difference is bigger } \\
\text { for prior-loss firms than for prior-profit } \\
\text { firms. }\end{array}$ \\
\hline $\begin{array}{l}\text { Tan, } \\
\text { Libby, and } \\
\text { Hunton } \\
\text { [2002, } \\
\text { JAR] }\end{array}$ & $\begin{array}{l}\text { Mental } \\
\text { accounting }\end{array}$ & $\begin{array}{l}\text { Total earnings news } \\
\text { valence (positive, } \\
\text { negative) } \\
\text { Guidance news in } \\
\text { proportion to total } \\
\text { earnings news ( } 50 \% \text {, } \\
100 \%, 150 \%)\end{array}$ & $\begin{array}{l}\text { Earnings re- } \\
\text { estimates after } \\
\text { actual earnings } \\
\text { announcement }\end{array}$ & $\begin{array}{l}\text { For positive total earnings news, earnings re- } \\
\text { estimates are higher (lower) when the news } \\
\text { is understated (overstated) in guidance than } \\
\text { when it is accurately stated in guidance. For } \\
\text { negative total earnings news, earnings re- } \\
\text { estimates are lower (higher) when the news } \\
\text { is understated (overstated) in guidance than } \\
\text { when it is accurately stated in guidance. }\end{array}$ \\
\hline
\end{tabular}




\begin{tabular}{|c|c|c|c|c|}
\hline $\begin{array}{l}\text { Mercer } \\
{[2005,} \\
\text { TAR] }\end{array}$ & $\begin{array}{l}\text { Attribution } \\
\text { theory and } \\
\text { affective } \\
\text { decision } \\
\text { theory }\end{array}$ & $\begin{array}{l}\text { Forthcomingness } \\
\text { (guiding, non-guiding) } \\
\text { News valence (positive, } \\
\text { negative) } \\
\text { Assessment horizon } \\
\text { (short, long) }\end{array}$ & $\begin{array}{l}\text { Management } \\
\text { credibility }\end{array}$ & $\begin{array}{l}\text { For a short-term assessment horizon, } \\
\text { management credibility is assessed higher } \\
\text { for a guiding firm than for a non-guiding } \\
\text { firm, and the difference is larger for negative } \\
\text { guidance than for positive guidance. For a } \\
\text { long-term assessment horizon, management } \\
\text { credibility is determined by news valence-- } \\
\text { higher credibility for positive news than for } \\
\text { negative news-and is not affected by } \\
\text { whether there is earnings guidance. }\end{array}$ \\
\hline $\begin{array}{l}\text { Kadous, } \\
\text { Krische, } \\
\text { and Sedor } \\
\text { [2006, } \\
\text { TAR] }\end{array}$ & $\begin{array}{l}\text { Counter- } \\
\text { explanation }\end{array}$ & $\begin{array}{l}\text { Number of counter- } \\
\text { explanations (no, few, } \\
\text { many) }\end{array}$ & $\begin{array}{l}\text { Earnings } \\
\text { estimates after } \\
\text { management } \\
\text { guidance }\end{array}$ & $\begin{array}{l}\text { Asking participants to generate a few } \\
\text { counter-explanations reduces their optimism } \\
\text { in earnings estimates induced by scenario } \\
\text { thinking, but asking them to generate many } \\
\text { counter-explanations does not reduce } \\
\text { optimism. }\end{array}$ \\
\hline $\begin{array}{l}\text { Libby, } \\
\text { Tan, and } \\
\text { Hunton } \\
\text { [2006, } \\
\text { TAR] }\end{array}$ & $\begin{array}{l}\text { Range } \\
\text { precision } \\
\text { effect }\end{array}$ & $\begin{array}{l}\text { Guidance error } \\
\text { (downward bias, upward } \\
\text { bias) } \\
\text { Guidance form (point, } \\
\text { narrow range, wide } \\
\text { range) }\end{array}$ & $\begin{array}{l}\text { Earnings re- } \\
\text { estimates after } \\
\text { actual earnings } \\
\text { announcement }\end{array}$ & $\begin{array}{l}\text { When the actual EPS exceeds (misses) the } \\
\text { point guidance (the midpoint of the range } \\
\text { guidance), investors' earnings reestimates } \\
\text { are highest (lowest) for the narrow range } \\
\text { guidance (where the actual EPS fall outside } \\
\text { of the range), followed by the point } \\
\text { guidance, then by the wide range guidance } \\
\text { (where the actual EPS fall within the range). }\end{array}$ \\
\hline $\begin{array}{l}\text { Miller } \\
\text { [2006, } \\
\text { CAR] }\end{array}$ & $\begin{array}{l}\text { Diminishin } \\
\text { g marginal } \\
\text { reactions } \\
\text { and cue } \\
\text { consistency } \\
\text { effect }\end{array}$ & $\begin{array}{l}\text { Guidance news in } \\
\text { proportion to total } \\
\text { earnings news (150\%, } \\
88.9 \% \text {, } 50 \%, 11.1 \% \text {, - } \\
50 \%)\end{array}$ & $\begin{array}{l}\text { Earnings re- } \\
\text { estimates after } \\
\text { actual earnings } \\
\text { announcement }\end{array}$ & $\begin{array}{l}\text { Earnings re-estimates are highest when } \\
\text { guidance news equals one-half of total } \\
\text { earnings news, followed by understated } \\
\text { guidance news (guidance news and actual } \\
\text { earnings news are consistent in sign), then } \\
\text { by overstated guidance news (guidance news } \\
\text { and actual earnings news are inconsistent in } \\
\text { sign). }\end{array}$ \\
\hline
\end{tabular}




\begin{tabular}{|c|c|c|c|c|}
\hline $\begin{array}{l}\text { Han and } \\
\text { Tan [2007, } \\
\text { TAR] }\end{array}$ & $\begin{array}{l}\text { Multiple- } \\
\text { reference- } \\
\text { points } \\
\text { theory }\end{array}$ & $\begin{array}{l}\text { Guidance form (point, } \\
\text { MID, range) } \\
\text { Investor knowledge (high, } \\
\text { low) }\end{array}$ & $\begin{array}{l}\text { Earnings re- } \\
\text { estimates after } \\
\text { actual earnings } \\
\text { announcement }\end{array}$ & $\begin{array}{l}\text { For high-knowledge participants, earnings } \\
\text { re-estimates are highest for range guidance, } \\
\text { followed by MID guidance, then by point } \\
\text { guidance, when earnings falls in the lower } \\
\text { end (missing the midpoint but above the } \\
\text { lower endpoint). For low-knowledge } \\
\text { participants, earnings re-estimates are not } \\
\text { different between the MID guidance and } \\
\text { point guidance conditions, and both are } \\
\text { lower than the range guidance condition. }\end{array}$ \\
\hline $\begin{array}{l}\text { Hirst, } \\
\text { Koonce, } \\
\text { and } \\
\text { Venkatara } \\
\text { man } \\
\text { [2007, } \\
\text { JAR] }\end{array}$ & $\begin{array}{l}\text { Disaggrega } \\
\text { t-ion } \\
\text { enhances } \\
\text { manage- } \\
\text { ment } \\
\text { credibility }\end{array}$ & $\begin{array}{l}\text { Earnings manipulation } \\
\text { incentives (high, low) } \\
\text { Guidance disaggregation } \\
\text { (aggregated, } \\
\text { disaggregated) }\end{array}$ & $\begin{array}{l}\text { Management } \\
\text { credibility }\end{array}$ & $\begin{array}{l}\text { For disaggregated guidance, management } \\
\text { incentive to manage earnings does not affect } \\
\text { management credibility. For aggregated } \\
\text { guidance, management credibility is higher } \\
\text { for managers with low (versus high) } \\
\text { incentive to manage earnings. }\end{array}$ \\
\hline $\begin{array}{l}\text { Libby, } \\
\text { Hunton, } \\
\text { Tan, and } \\
\text { Seybert } \\
\text { [2008, } \\
\text { JAR] }\end{array}$ & $\begin{array}{l}\text { Analysts' } \\
\text { forecasts } \\
\text { are driven } \\
\text { by their } \\
\text { economic } \\
\text { incentives }\end{array}$ & $\begin{array}{l}\text { Analysts' incentive } \\
\text { (accuracy, relationship) } \\
\text { Guidance timing (early, } \\
\text { late) }{ }^{3}\end{array}$ & $\begin{array}{l}\text { Earnings re- } \\
\text { estimates after } \\
\text { actual earnings } \\
\text { announcement }\end{array}$ & $\begin{array}{l}\text { Analysts' earnings forecasts exhibit an } \\
\text { optimistic-to-pessimistic pattern (being } \\
\text { optimistic early then later become } \\
\text { pessimistic), and this pattern is more } \\
\text { obvious for those analysts have the } \\
\text { relationship incentive. }\end{array}$ \\
\hline $\begin{array}{l}\text { Venkatara } \\
\text { man } \\
{[2008 \text {, }} \\
\text { WP] }\end{array}$ & $\begin{array}{l}\text { Omission } \\
\text { bias theory }\end{array}$ & $\begin{array}{l}\text { Guidance commitment } \\
\text { (more, less committed) } \\
\text { Prior guidance accuracy } \\
\text { (high, low) }\end{array}$ & $\begin{array}{l}\text { Management } \\
\text { credibility }\end{array}$ & $\begin{array}{l}\text { Committed disclosers (those firms with a } \\
\text { regular and predictable guidance record) are } \\
\text { viewed as more (less) credible than less } \\
\text { committed disclosers when prior forecasts } \\
\text { are more (less) accurate. }\end{array}$ \\
\hline
\end{tabular}




\begin{tabular}{|c|c|c|c|c|}
\hline $\begin{array}{l}\text { Du [2009, } \\
\text { JBF] }\end{array}$ & $\begin{array}{l}\text { Ambiguity } \\
\text { theory }\end{array}$ & $\begin{array}{l}\text { Guidance news (positive, } \\
\text { negative) } \\
\text { Guidance form (point, } \\
\text { range) }\end{array}$ & $\begin{array}{l}\text { Investors' } \\
\text { resource } \\
\text { allocation } \\
\text { decision } \\
\end{array}$ & $\begin{array}{l}\text { When guidance news is positive (negative), } \\
\text { investors allocate more resource to the firm } \\
\text { issuing range (point) guidance where there is } \\
\text { more (less) ambiguity. }\end{array}$ \\
\hline $\begin{array}{l}\text { Fleming } \\
\text { [2009, } \\
\text { BRIA] }\end{array}$ & $\begin{array}{l}\text { Expectancy } \\
\text { Violation } \\
\text { Theory }\end{array}$ & $\begin{array}{l}\text { Guidance disaggregation } \\
\text { (disaggregated, } \\
\text { aggregated) } \\
\text { Guidance form (point, } \\
\text { range) }\end{array}$ & $\begin{array}{l}\text { Venture } \\
\text { capitalists' } \\
\text { initial } \\
\text { investment } \\
\text { screening } \\
\text { decision } \\
\end{array}$ & $\begin{array}{l}\text { Disaggregated guidance leads to better } \\
\text { (worse) screening decision than aggregated } \\
\text { guidance for point (range) guidance. }\end{array}$ \\
\hline $\begin{array}{l}\text { Han and } \\
\text { Tan }[2010 \text {, } \\
\text { JAR] }\end{array}$ & $\begin{array}{l}\text { Motivated } \\
\text { reasoning } \\
\text { and elastic } \\
\text { justificatio } \\
\mathrm{n} \text { theory }\end{array}$ & $\begin{array}{l}\text { Investor position (long, } \\
\text { short) } \\
\text { Guidance news valence } \\
\text { (positive, negative) } \\
\text { Guidance form (point, } \\
\text { range) }\end{array}$ & $\begin{array}{l}\text { Earnings } \\
\text { estimates after } \\
\text { management } \\
\text { guidance }\end{array}$ & $\begin{array}{l}\text { Motivated reasoning (long investors make } \\
\text { higher earnings estimates than short } \\
\text { investors) is more likely to occur for range } \\
\text { guidance than for point guidance, and more } \\
\text { likely for positive guidance than for negative } \\
\text { guidance. }\end{array}$ \\
\hline $\begin{array}{l}\text { Tan, } \\
\text { Libby, and } \\
\text { Hunton } \\
\text { [2010, } \\
\text { CAR] }\end{array}$ & $\begin{array}{l}\text { Elastic } \\
\text { justificatio } \\
\text { n theory }\end{array}$ & $\begin{array}{l}\text { Analysts' incentive } \\
\text { (accuracy, relationship) } \\
\text { Management guidance } \\
\text { bias record (consistent, } \\
\text { inconsistent) }\end{array}$ & $\begin{array}{l}\text { Earnings } \\
\text { estimates after } \\
\text { management } \\
\text { guidance }\end{array}$ & $\begin{array}{l}\text { Analysts adjust for guidance bias when they } \\
\text { have accuracy objective but not so for } \\
\text { relationship objective. The difference } \\
\text { between these two analysts groups is greater } \\
\text { for a consistent guidance record than for an } \\
\text { inconsistent guidance record. }\end{array}$ \\
\hline $\begin{array}{l}\text { Du, } \\
\text { Budescu, } \\
\text { Shelly, } \\
\text { and Omer } \\
\text { [2011, } \\
\text { OBHDP] }\end{array}$ & $\begin{array}{l}\text { Congruity } \\
\text { theory \& } \\
\text { ambiguity } \\
\text { aversion } \\
\text { theory }\end{array}$ & $\begin{array}{l}\text { Information vagueness } \\
\text { (high, low) } \\
\text { Guidance form (point, } \\
\text { narrow range, and wide } \\
\text { range) }\end{array}$ & $\begin{array}{l}\text { Investors' } \\
\text { preferences for } \\
\text { more precise } \\
\text { guidance form }\end{array}$ & $\begin{array}{l}\text { Investors prefer more (less) precise point } \\
\text { (range) guidance form when the information } \\
\text { given is less (more) ambiguous. Investors } \\
\text { prefer narrow range to wide range guidance. }\end{array}$ \\
\hline $\begin{array}{l}\text { Elliott, } \\
\text { Hobson, } \\
\text { and } \\
\text { Jackson }\end{array}$ & $\begin{array}{l}\text { Activation } \\
\text { of different } \\
\text { knowledge } \\
\text { schemes }\end{array}$ & $\begin{array}{l}\text { Guidance disaggregation } \\
\text { (Aggregated, } \\
\text { disaggregated) } \\
\text { Actual earnings outcome }\end{array}$ & $\begin{array}{l}\text { Investment } \\
\text { attractiveness }\end{array}$ & $\begin{array}{l}\text { Earnings fixation is lower for disaggregated } \\
\text { than for aggregated guidance. }\end{array}$ \\
\hline
\end{tabular}




\begin{tabular}{|c|c|c|c|c|}
\hline $\begin{array}{l}\text { [2011, } \\
\text { TAR] }\end{array}$ & $\begin{array}{l}\text { associated } \\
\text { with } \\
\text { earnings }\end{array}$ & (favorable, unfavorable) & & \\
\hline $\begin{array}{l}\text { Hales, } \\
\text { Kuang, } \\
\text { and } \\
\text { Venkatara } \\
\text { man } \\
\text { [2011, } \\
\text { JAR] }\end{array}$ & $\begin{array}{l}\text { Motivated } \\
\text { reasoning } \\
\text { and } \\
\text { vividness } \\
\text { effect }\end{array}$ & $\begin{array}{l}\text { Investor position (long, } \\
\text { short) } \\
\text { Language vividness } \\
\text { (vivid, pallid) }\end{array}$ & $\begin{array}{l}\text { Earnings } \\
\text { growth }\end{array}$ & $\begin{array}{l}\text { For positive news, short investors who } \\
\text { receive vivid presentation assess higher } \\
\text { future earnings growth than those who } \\
\text { receive pallid presentation. Long investors } \\
\text { are less affected by presentation vividness. } \\
\text { For negative news, long investors who } \\
\text { receive vivid presentation assess lower } \\
\text { future earnings growth than those who } \\
\text { receive pallid presentation. Short investors } \\
\text { are less affected by presentation vividness. }\end{array}$ \\
\hline $\begin{array}{l}\text { Holdernes } \\
\text { s and } \\
\text { Hunton } \\
\text { [2011, } \\
\text { WP] }\end{array}$ & $\begin{array}{l}\text { Strategic } \\
\text { information } \\
\text { transmissio } \\
\mathrm{n} \text { theory } \\
\text { and } \\
\text { anticipator } \\
\mathrm{y} \\
\text { obfuscation } \\
\text { theory }\end{array}$ & $\begin{array}{l}\text { Earnings management } \\
\text { pressure (absent, present) } \\
\text { Disaggregated guidance } \\
\text { pressure (absent, present) }\end{array}$ & $\begin{array}{l}\text { What Income } \\
\text { Statement items } \\
\text { to disclose in } \\
\text { their earnings } \\
\text { guidance }\end{array}$ & $\begin{array}{l}\text { Managers who are under pressure to manage } \\
\text { earnings choose to aggregate information } \\
\text { where earnings management takes place } \\
\text { (i.e., not to disclose) and disaggregate } \\
\text { guidance in other places (i.e., to disclose). } \\
\text { Managers who are not under pressure to } \\
\text { manage earnings do not exhibit such a } \\
\text { guidance disaggregation pattern. }\end{array}$ \\
\hline $\begin{array}{l}\text { Maletta } \\
\text { and Zhang } \\
\text { [2011, } \\
\text { CAR] }\end{array}$ & $\begin{array}{l}\text { Contrast } \\
\text { effect }\end{array}$ & $\begin{array}{l}\text { Guidance news in } \\
\text { proportion to total news } \\
\text { (25\%, 50\%, 75\%) } \\
\text { Guidance provider (own } \\
\text { firm, peer firm) }\end{array}$ & $\begin{array}{l}\text { Earnings re- } \\
\text { estimates after } \\
\text { actual earnings } \\
\text { announcement }\end{array}$ & $\begin{array}{l}\text { When there is no difference in terms of } \\
\text { percentage of guidance news relative to total } \\
\text { earnings news between the target and peer } \\
\text { firms, investor re-estimates for the target } \\
\text { firm are higher when } 50 \% \text { of the total } \\
\text { earnings news is released in guidance. } \\
\text { When there is a difference in terms of } \\
\text { percentage of guidance news relative to total } \\
\text { earnings news between the target and the } \\
\text { peer firms, investors' re-estimates for the } \\
\text { target firm are higher if the target firm }\end{array}$ \\
\hline
\end{tabular}


releases more positive news in guidance

(than the peer firm).

\begin{tabular}{|c|c|c|c|c|}
\hline $\begin{array}{l}\text { Nelson } \\
\text { and Rupar } \\
\text { [2011, } \\
\text { WP] }\end{array}$ & $\begin{array}{l}\text { Ratio bias } \\
\text { effect }\end{array}$ & $\begin{array}{l}\text { Numerical format (dollar, } \\
\text { percentage) } \\
\text { Disclosure management } \\
\text { opportunity (mandatory, } \\
\text { voluntary) } \\
\text { Disclosure management } \\
\text { incentive (low, high) }\end{array}$ & $\begin{array}{l}\text { Investment risk } \\
\text { perception }\end{array}$ & $\begin{array}{l}\text { For the mandatory disclosure format, } \\
\text { investor risk assessment is higher for dollar } \\
\text { disclosure than for percentage disclosure in } \\
\text { the sensitivity analysis. } \\
\text { For the discretionary disclosure format, } \\
\text { investor risk assessment is not different } \\
\text { between dollar and percentage disclosure in } \\
\text { the sensitivity analysis. }\end{array}$ \\
\hline $\begin{array}{l}\text { Rupar } \\
{[2011 \text {, }} \\
\text { WP] }\end{array}$ & $\begin{array}{l}\text { Attribution } \\
\text { theory }\end{array}$ & $\begin{array}{l}\text { Guidance form (point, } \\
\text { range) } \\
\text { Environmental uncertainty } \\
\text { (high, low) }\end{array}$ & $\begin{array}{l}\text { Management } \\
\text { credibility, } \\
\text { Firm growth } \\
\text { expectations, } \\
\text { Stock price } \\
\text { estimates }\end{array}$ & $\begin{array}{l}\text { Within each uncertainty setting, when } \\
\text { management guidance form is aligned with } \\
\text { its operating environment uncertainty (i.e., } \\
\text { point/range guidance for low/high } \\
\text { uncertainty), management credibility is } \\
\text { assessed to be higher, which in turn leads to } \\
\text { higher growth expectations and higher stock } \\
\text { price estimates, relative to when } \\
\text { management guidance form is misaligned } \\
\text { with its operating environment uncertainty } \\
\text { (i.e., point/range guidance for high/low } \\
\text { uncertainty). }\end{array}$ \\
\hline $\begin{array}{l}\text { Tan and } \\
\text { Koonce } \\
\text { [2011, } \\
\text { AOS] }\end{array}$ & $\begin{array}{l}\text { Affect } \\
\text { theory }\end{array}$ & $\begin{array}{l}\text { Guided EPS (low, high) } \\
\text { Retraction \& correction } \\
\text { (both retraction \& } \\
\text { correction, correction } \\
\text { only) }\end{array}$ & $\begin{array}{l}\text { Earnings } \\
\text { potential, } \\
\text { investment } \\
\text { attractiveness }\end{array}$ & $\begin{array}{l}\text { When guidance news is retracted, investors } \\
\text { cannot fully eliminate the impact of previous } \\
\text { erroneous disclosure. When guidance news } \\
\text { is retracted and corrected, investors tend to } \\
\text { over-react by overweighting the new } \\
\text { corrected news. }\end{array}$ \\
\hline $\begin{array}{l}\text { Libby and } \\
\text { Rennekam } \\
\text { p [2012, } \\
\text { JAR] }\end{array}$ & $\begin{array}{l}\text { Over- } \\
\text { confidence }\end{array}$ & $\begin{array}{l}\text { Task difficulty (easy, } \\
\text { difficult) }\end{array}$ & $\begin{array}{l}\text { Commitment to } \\
\text { high } \\
\text { performance in } \\
\text { second round }\end{array}$ & $\begin{array}{l}\text { Overconfident managers (for whom the } \\
\text { overconfidence is induced by an easy task) } \\
\text { are more likely provide earnings guidance. }\end{array}$ \\
\hline
\end{tabular}




\begin{tabular}{|c|c|c|c|c|}
\hline $\begin{array}{l}\text { Rennekam } \\
\text { p [2012, } \\
\text { JAR] }\end{array}$ & $\begin{array}{l}\text { Processing } \\
\text { fluency }\end{array}$ & $\begin{array}{l}\text { News nature (positive, } \\
\text { negative) } \\
\text { Readability (high, low) }\end{array}$ & $\begin{array}{l}\text { Valuation } \\
\text { judgment; } \\
\text { management } \\
\text { credibility }\end{array}$ & $\begin{array}{l}\text { More readable disclosures make investors' } \\
\text { reaction to positive (negative) guidance } \\
\text { more positive (negative) compared to less } \\
\text { readable disclosures. }\end{array}$ \\
\hline
\end{tabular}

\begin{tabular}{|c|c|c|c|c|}
\hline $\begin{array}{l}\text { Tan, } \\
\text { Wang, and } \\
\text { Zhou } \\
\text { [2012, } \\
\text { WP] }\end{array}$ & $\begin{array}{l}\text { Readability } \\
\text { effect; } \\
\text { message } \\
\text { consistency } \\
\text { effect }\end{array}$ & $\begin{array}{l}\text { Message consistency } \\
\text { (high, low) } \\
\text { Language readability } \\
\text { (high, low) }\end{array}$ & $\begin{array}{l}\text { Disclosure } \\
\text { credibility } \\
\text { Valuation } \\
\text { judgment }\end{array}$ & $\begin{array}{l}\text { Readability matters only when messages are } \\
\text { inconsistent, but not when messages are } \\
\text { consistent. } \\
\text { When messages are inconsistent, more } \\
\text { readable disclosures lead to higher } \\
\text { disclosure credibility, and also higher } \\
\text { valuation judgment, than less readable } \\
\text { disclosures. }\end{array}$ \\
\hline
\end{tabular}

\begin{tabular}{|c|c|c|c|c|}
\hline $\begin{array}{l}\text { Wang and } \\
\text { Tan [2013, } \\
\text { JAR] }\end{array}$ & $\begin{array}{l}\text { Mental } \\
\text { accounting } \\
\text { and goal } \\
\text { setting } \\
\text { theory }\end{array}$ & $\begin{array}{l}\text { Guidance frequency } \\
\text { (frequent, infrequent) } \\
\text { Guidance goal (accurate, } \\
\text { beat/meet) }\end{array}$ & $\begin{array}{l}\text { Marketing } \\
\text { strategy } \\
\text { preference and } \\
\text { choice }\end{array}$ & $\begin{array}{l}\text { Frequent guiders tend to prefer the } \\
\text { marketing strategy with more predictable } \\
\text { quarterly earnings (but with lower total } \\
\text { expected earnings) than infrequent guiders. } \\
\text { Accuracy-goal guiders tend to prefer the } \\
\text { marketing strategy with higher predictable } \\
\text { quarterly earnings (but with lower total } \\
\text { expected earnings) than beat/meet-goal } \\
\text { guiders. } \\
\text { The difference in preference between } \\
\text { guiders with different goals is smaller for } \\
\text { frequent guiders than for infrequent guiders. }\end{array}$ \\
\hline
\end{tabular}

\footnotetext{
${ }^{1}$ This table summarizes the theory, main independent variables, main dependent variables, and key research findings of the 29 papers reviewed.

${ }^{2} \mathrm{I}$ include the journal name in brackets. JAR is a short for Journal of Accounting Research, TAR is a short for The Accounting Review, CAR is a short for Contemporary Accounting Research, AOS is a short for Accounting, Organization, and Society, BRIA is a short for Behavioral Research in Accounting, JBF is a short for Journal of Behavioral Finance, OBHDP is a short for Organizational Behavior and Human Decision Processes, and WP stands for working paper.
} 
${ }^{3}$ Based on Experiment 1.

${ }^{4}$ Based on Experiments 3 and 4, which are related to sensitivity disclosure. 